\title{
Erratum
}

Journal of Microbiology (2016) Vol. 54, No. 12, pp. 809-813

DOI 10.1007/s12275-016-6473-1

\section{Bacillus piscis sp. nov., a novel bacterium isolated from the muscle of the antarctic fish Dissostichus mawsoni}

\author{
Jae-Bong Lee ${ }^{1}$, Seon Hwa Jeon ${ }^{2}$, Seok-Gwan Choi ${ }^{1}$, Hee-Young Jung ${ }^{3,4}$, \\ Myung Kyum Kim ${ }^{2 \star}$, and Sathiyaraj Srinivasan ${ }^{2 \star}$ \\ ${ }^{l}$ Distant-water Fisheries Resources Division, National Institute of Fisheries Science, Busan 46083, Republic Korea \\ ${ }^{2}$ Department of Bio and Environmental Technology, College of Natural Science, Seoul Women's University, Seoul 01797, Republic Korea \\ ${ }^{3}$ College of Agricultural and Life Sciences, Kyungpook National University, Daegu 41566 Republic Korea \\ ${ }^{4}$ Institute of Plant Medicine, Kyungpook National University, Daegu 41566, Republic Korea
}

In the article by Lee et al. published in Journal of Microbiology 2016; 54, 809-813, The KCTC accession number KCTC $18866^{\top}$ in abstract and foot note should be corrected to KCTC $33839^{\top}$.

The sentence in abstract should have read: Based on the phylogenetic, phenotypic, and chemotaxonomic data, strain $16 \mathrm{MFT} 21^{\top}$ $\left(=\right.$ KCTC $33839^{\top}=$ JCM $\left.31664^{\top}\right)$.

The species description in foot note should have read: The NCBI GenBank/EMBL/DDBJ accession number for the 16S rRNA gene sequence of strain $16 \mathrm{MFT} 21^{\top}\left(=\mathrm{KCTC} 33839^{\top}=\mathrm{JCM} 31664^{\top}\right)$ is $\mathrm{KX} 753358$.

We apologize for any inconvenience that this may have caused. 